\title{
LATVIJAS VESELĪBAS APRŪPES VADĪBA (HRONOLOGISKI SARAKSTI)
}

\section{Labklājības ministri}

Neatkarīgās Latvijas valsts sākotnē tautas labklājības jautājumus no 1919. gada pārzināja Iekšlietu ministrijas Sociālais departaments un Veselības departaments. Valdības reorganizācijas gaitā 1920. gadā Sociālo departamentu pārveidoja par patstāvīgu Darba ministriju (darba ministra posteni, cits citu nomainot, ieṇēma seši cilvēki). Nākamajā reorganizācijā 1925. gadā Darba ministriju părveidoja par Tautas labklājības ministriju, tai pievienojot Veselības departamentu, ko atdalīja no Iekšlietu ministrijas. Saskañã ar 1931. gadā pieñemto likumu par Tautas labklājības ministriju tâs sastāvā bija trīs departamenti: Darba aizsardzības departaments, Sociālās apgādības departaments un Veselības departaments, kā arī Farmācijas pārvalde (ar departamenta tiesỉbām).

Pēc padomju okupãcijas t.s. Tautas valdības sastāvã Tautas labklājības ministrija turpināja darboties no 1940. gada jūnija līdz augustam, kad tika likvidēta, valsts varas ešelonam reorganizējoties pēc padomju parauga un izveidojot Sociālās nodrošināšanas tautas komisariātu un Veselības aizsardzības tautas komisariātu (no 1946. gada - ministrijas).

Vienota ministrija tika atjaunota 1991. gadā, bet ne vairs kā Tautas labklājības ministrija, bet kā Labklājības ministrija. Tãs struktūras pamatu veidoja likvidētās Sociālās nodrošināŠanas ministrija un Veselības aizsardzības ministrija, kā arī divi Ekonomikas ministrijas departamenti. Pilnveidojoties iekšējai struktūrai, Labklājības ministrijas departamentu skaits vêlāk pieauga līdz desmit.

No labklājības ministriem četri ir ārsti (T. Eniņš, R. Jurdžs, A. Požarnovs, V. Jaksons), bet viens - farmaceits (V. Rubulis). 


\begin{tabular}{|c|c|}
\hline Darbības laiks & Ministrs \\
\hline $1925-1925$ & Voldemārs Salnais (1886-1948) \\
\hline $1925-1926$ & Vladislavs Rubulis (1887-1937) \\
\hline $1926-1928$ & Ansis Rudevics (1890-1974) \\
\hline $1928-1934$ & Vladislavs Rubulis (1887-1937) \\
\hline 1934-1934 & Juris Pabērzs (1891-1961) \\
\hline $1934-1937$ & Vladislavs Rubulis (1887-1937) \\
\hline $1937-1937$ & Hermanis Apsītis (1893-1942) ${ }^{1}$ \\
\hline $1938-1940$ & Jānis Volonts (1882-1943?) \\
\hline $1940-1940$ & Jūlijs Lācis (1892-1941) \\
\hline $1991-1993$ & Teodors Eniņš (dz. 1934) \\
\hline 1993-1994 & Jānis Ritenis (dz. 1925) \\
\hline $1994-1995$ & Andris Bērziṇš (dz. 1951) \\
\hline $1995-1999$ & Vladimirs Makarovs (dz. 1957) \\
\hline 1999-2000 & Roberts Jurdžs (1963-2002) \\
\hline $2000-2002$ & Andrejs Požarnovs (dz. 1962) \\
\hline Kopš 2002 & Viktors Jaksons (dz. 1947) \\
\hline
\end{tabular}

\section{Latvijas veselības aprūpes vadītāji}

Pirmais nosacĩtais Latvijas valstiskais veidojums bija Latvijas Strādnieku, kareivju un bezzemnieku deputātu padomes izpildkomiteja jeb t.s. Iskolats, bet pirmā vadošã veselības aprūpes iestāde - Latvijas Strādnieku, kareivju un bezzemnieku deputātu padomes izpildkomitejas Sanitārā noda|a, kas darbojās no 1917. gada decembra līdz 1918. gada februārim Valkā. Sekojošã vācu okupăcijas laikâ visai Latvijai vienota un līdzīga rakstura iestāde nepastāvēja.

LSPR valdības Tautas veselības komisariāts tika izveidots 1919. gada janvārī Rīgā, bet maijā to părcēla uz Rēzekni, kur tas darbojās līdz 1920. gada janvārim.

Tostarp Latvijas Republikas Pagaidu valdība 1919. gada otrajā pusē bija izveidojusi Veselības departamentu, kas līdz 1925, gadam ietilpa lekšlietu ministrijas, pēc tam - Tautas labklājības ministrijas sastāvā.

Pēc padomju okupācijas Veselības departaments tika saglabāts pārejas posmã no 1940. gada jūlija lĩdz septembrim un to vadīja direktora atvietotājs. Pēc tam tika izveidots LPSR Veselības aizsardzības tautas komisariāts, kas kara laikā turpināja formālu darbību frontes aizmugurē PSRS iekšienē.

\footnotetext{
1 Atvietotājs.
} 
Vãcu okupācijas laikā darbojās Latvijas generālapgabala Iekšlietu direkcijas Veselïbas departaments.

No 1944. līdz 1946. gadam atkal darbojās LPSR Veselības aizsardzỉbas tautas komisariāts, turpmāk līdz 1990. gadam - LPSR Veselības aizsardzības ministrija un vēl vienu gadu - LR Veselības aizsardzības ministrija.

Pēc tās likvidācijas Latvijas Republikas Labklājīibas ministrijas ietvaros 1991. gadā tika atjaunots Veselības departaments (no 1997. gada līdz 2001. gada tika saukts par Ārstniecības departamentu), kuru vada direktors. Virsvadībai 1993. gadā tika izveidots labklājīibas ministram pakjauts veselības ministra amats, kas tika aizṇemts ar nelieliem pārtraukumiem līdz 1999. gadam, kad tika likvidēts. Tādējāidi pašlaik iedzīvotāju veselības aprūpes darbu vada Veselības departamenta direktors, dažas no savām funkcijām dalot ar Vides veselïbas departamenta direktoru un Farmācijas departamenta direktoru.

Sarakstā hronologiskā secībā ieklauti Iskolata Sanitārās nodaḷas vadītāji (divi), LR Veselības departamenta direktori (pieci) un direktora aizstājẹjs pārejas posmā 1940. gadā (viens), LPSR veselības aizsardzības tautas komisāri (četri; ieskaitot formālus pienākuma veicējus ārpus Latvijas teritorijas kara laikā frontes padomju pusē), vācu laika Veselības departamenta direktori (divi), LPSR veselības aizsardzības ministri (Četri; pēdējais no viniem ir arī pirmais un vienīgais LR veselības aizsardzības ministrs), LR Veselības departamenta direktors (viens; laikā, kad nepastāvēja veselības valsts ministra postenis), veselības valsts ministri (četri) un Veselïbas (Ārstniecības) departamenta direktori (divi; pēc veselības valsts ministra posteṇa likvidēšanas).

No sarakstā ietvertajāmm personām trīs (E. Pumpurs, I. Trinklers, E. Ameriks) nav bijuši ărsti.

$\begin{array}{ll}\begin{array}{l}\text { Darbības laiks } \\ \text { 1917-1917 }\end{array} & \text { Vadītājs } \\ 1917-1918 & \text { Andrejs Priedkalns (1873-1923) } \\ \text { Marija Vecrumba (1885-1919) } \\ 1919-1919 & \text { Kārlis Ādamsons (1884-1958) } \\ 1919-1920 & \text { Eduards Pumpurs (?-1937?) } \\ 1920-1922 & \text { Gustavs Reinhards (1868-1937) } \\ 1922-1925 & \text { Kārlis Barons (1865-1944) } \\ 1925-1935 & \text { Jānis Kivickis (1864-1943) } \\ 1935-1940 & \text { Ougusts Pētersons (1878-1966) } \\ 1940-1940 & \text { Jānis Skuja (1886-1983) }\end{array}$

2

LSPR valdības sastāvā. 


\begin{tabular}{|c|c|}
\hline $1940-1943$ & Emīls Planders $(1906-1983)^{3}$ \\
\hline $1941-1942$ & Erihs Bušs (1903-1973) ${ }^{4}$ \\
\hline $1942-1944$ & Teodors Vankins (1873-1947) \\
\hline $43-1944$ & Ivans Trinklers $(1901-1976)^{5}$ \\
\hline $44-1944$ & Augusts Kalniņš (1894-1986) 3 \\
\hline $44-1946$ & Ernests Ameriks (1897-1977) \\
\hline $6-1958$ & Ādolfs Krauss (1905-1958) \\
\hline $59-1962$ & Vladimirs Ozoliņš (1909-1975) \\
\hline $62-1989$ & Vilhelms Kaneps (1923-1993) \\
\hline 89-1991 & Edvīns Platkājis (dz. 1938) \\
\hline $91-1993$ & Zigmunds Kova|čuks (dz. 1950) \\
\hline $93-1995$ & Normunds Zemvaldis (dz. 1958) \\
\hline $95-1995$ & Pēteris Apinis (dz. 1958) \\
\hline 95-1997 & Juris Vinkelis (dz. 1952) \\
\hline $7-1999$ & Viktors Jaksons (dz. 1947) \\
\hline $9-2001$ & Oskars Velmers (dz. 1944) \\
\hline 52001 & Renāte Pupele (dz. 1953) \\
\hline
\end{tabular}

\section{Latvijas Ārstu biedrības vadītāji}

Rīgas Praktizējošo ârstu biedrība dibināta 1822. gadā, Jelgavas Praktizējošo ârstu biedrība - 1939. gadā, Daugavpils Medicīnas biedrība - 1882. gadā, Rīgas Krievu ārstu biedrība - 1888. gadā, Liepājas Praktizējošo ārstu biedrība - 1892. gadā, Zieme|kurzemes Ārstu biedrība - 1892. gadā, Latviešu ãrstu biedrība - 1902. gadā utt. Ārsti vienojās gan pēc nacionālas, gan teritoriālas piederības, bet speciālistu biedrības sāka veidoties 20. gs. divdesmitajos gados. 1932. gadā Latvijā bija regiistrētas 32 ărstu biedrības un organizācijas, 1987. gadā - 39 medicīnas zinātniskās biedrības.

Vienota Latvijas Ārstu biedrība izveidota 1939 gadā, likvidēta 1940. gadā un atjaunota 1988. gadā.

3 Dalēji ârpus Latvijas teritorijas, PSRS iekšienē.

4 Vācu okupācijas laikā.

5 Ārpus Latvijas teritorijas ,PSRS iekšienē. 


$\begin{array}{ll}\text { Vadības laiks } & \text { Prezidenti } \\ \text { 1939-1940 } & \text { Augusts Silarājs (1887-1966) } \\ \text { 1988-1990 } & \text { Ivars Krastiňš (dz. 1955) } \\ \text { 1991-1992 } & \text { Pēteris Apinis (dz. 1958) } \\ \text { 1992-1999 } & \text { Andrejs Požarnovs (dz. 1962) } \\ \text { Kopš 1999 } & \text { Viesturs Boka (dz. 1948) } \\ & \text { Viceprezidenti } \\ 1988-1990 & \text { Ilmārs Lazovskis (dz. 1931) } \\ 1988-1990 & \text { Vladimirs Strazdinš (dz. 1954) } \\ 1990-1992 & \text { Jānis Meikšāns (dz. 1959) } \\ \text { 1991-1992 } & \text { Normunds Zemvaldis (dz. 1958) } \\ 1992-1995 & \text { Pēteris Apinis (dz. 1958) } \\ \text { 1992-1999 } & \text { Arnis Eṇgelis (dz. 1953) } \\ 1995-1999 & \text { Viesturs Šilinš̌ (dz. 1950) } \\ 1999-2000 & \text { Andrejs Požarnovs (dz. 1962) } \\ \text { Kopš 1999 } & \text { Ilze Aizsilniece (dz. 1966) } \\ \text { Kopš 1999 } & \text { Uldis Kalniṇš (dz. 1946) }\end{array}$

\section{Rīgas veselības aprūpes vadītāji (1919-2001)}

Latvijā visvecākã medicīnas administratīvā sistēma ir Rĩgas pilsētai, kura izveidota jau viduslaikos un tiešu vēsturisku pēctecỉbu saglabā lĩdz mūsu dienām. 1360. gadā nodibināja pilsētas fiziḳa (ārsta) posteni, ko pirmais ieṇēma ḳinurgu un bărddziṇu cunftes meistars Heinrihs. Viña pienākumos, līdztekus trūcīgo iedzīvotāju ārstnieciskai aprūpei, ietilpa epidēmiju ierobežošana, pilsētas sanitārā uzraudzība, tiesu medicīnas ekspertīze u.c. No 16. gs. pilsētas fizikis jau bija akadēmiski izglittots ărsts ar medicīnas doktora grādu.

Pieaugot darba apjomam, pilsēta no 1626. gada algoja divus ārstus - pirmo un otro fiziḳi (vicefiziķi), kuru amatus 18. gs. beigās pārdēvēja par pirmo un otro pilsētas ârstu. Plašāka pilsētas medicīnas un sanitārā dienesta organizācija izveidojās 19. gs. Vispirms 1802. gadā nodibināja Trūcīgo aizgādniecỉbu jeb direktorātu, kas sekmēja ârstnieciskās palīdzỉbas uzlabošanu pilsētã un pastāvệja līdz 1904. gadam. No 1867. gada darbojās pilsētas domes Sanitărā komisija, tai līdztekus no 1904. gada - Slimnīcu komisija. Abas (ar nelielu pārtraukumu 1919. gadā) jau kã noda|as pastāvēja līdz 1921. gadam.

Padomju varas laikā 1919. gadā no janvāra līdz maijam darbojās Rīgas apriṇḳa Tautas veselības noda|a, kuras pārzin̄ā bija pilsētas slimnīcas, epidēmiju apkarošana, sanitāro apstāklu uzlabošana u.c. Latvijas Republikā šo darbu veica pilsētas Veselības nodala (vēlāk - Veselības valde), ko izveidoja 1921. gadā, apvienojot Sanităro nodaḷu un Slimnīcu noda|̣u. Pẽc padomju okupācijas 1940. gadā Vese- 
lības valdi reorganizēja un nosauca par Veselības aizsardzības nodalu, bet pēc nākamās varas maiṇas 1941. gada vasarā - par Veselības pārvaldi, un no 1944. gada rudens - atkal par Veselības aizsardzỉbas nodalu.

Atjaunotā Latvijas Republikā Veselības aizsardzības noda|u 1993. gadā pārdēvēja par Rīgas Domes Veselības pârvaldi, bet 1998. gadā to likvidēja sakarā ar Rīgas novada slimokases izveidošanu. Tā kā slimokase visas agrākās funkcijas tomêr nespēja pārṇemt, 1999. gadā atjaunoja iepriekšējo struktūru ar citu nosaukumu pilsētas Domes Labklājības departamenta Veselības aprūpes pārvalde.

\begin{tabular}{|c|c|}
\hline Vadības laiks & Vadītājs \\
\hline $1919-1921$ & Izāks Jofe $(1871-1942)^{6}$ \\
\hline $1919-1920$ & Pēteris Sniķers (1875-1944) 7 \\
\hline $1920-1921$ & Pauls Kalniņš $(1872-1945)^{7}$ \\
\hline $1921-1921$ & Jēkabs Alksnis (1870-1957) 7 \\
\hline $1921-1922$ & Izāks Jofe (1871-1942) \\
\hline $1922-1926$ & Nohums Grīnšteins (1873-1926) \\
\hline $1926-1934$ & Rūdolfs Blūmentāls (1882-1941) \\
\hline $1934-1935$ & Ernests Jansons (1880-1945) \\
\hline $1935-1940$ & Arvēds Kēse (1889-1973) \\
\hline $1940-1940$ & Mihails Jofe (1898-1979) \\
\hline $1940-1941$ & Vilhelms Pampe (1898-1975) \\
\hline $1941-1942$ & Oskars Viksninš (1887-1957) \\
\hline $1943-1944$ & Haralds Kiršentāls (1897-1978) \\
\hline $1944-1947$ & Vilhelms Pampe (1898-1975) \\
\hline $1947-1951$ & Olga Generalova (1898-1982) \\
\hline $1951-1956$ & Nina Teplakova (1909-?) \\
\hline $1956-1972$ & Zoja Orlova (dz. 1924) \\
\hline $1972-1981$ & Mārtiņš Rempe (dz. 1936) \\
\hline $1981-1985$ & Ojārs Forstmanis (1931-1998) \\
\hline $1985-1991$ & Anna Saprikova (1934-2001) \\
\hline $1992-1992$ & Anda Grigāne (dz. 1954) \\
\hline $992-1994$ & Anna Kalke (dz. 1943) \\
\hline
\end{tabular}


1994-1998

Andris Glāzītis (dz. 1949)

1999-2001 Uldis Čāčus (dz. 1944)

Kopš 2001 Mārtiņš Rempe (dz. 1936)

The Leadership of Latvia's Health Care (Summary)

By Arnis Vîksna

The article reviews all instances of independent Latvia, which survey problems of national welfare; the names of all welfare ministers beginning from the year 1925 up to 2001 are enumerated. In the same way a chronological survey up to our days is given of all Latvia's welfare workers from 1917 and those of Riga from 1919. Besides, the article presents all the presidents and vice-presidents of Latvia's Doctors Associate.

Arnis Vīksna, Dr.habil.med., prof., LZA akad.

LU Medicīnas fakultāte

Raina bulv. 19

Rīga LV-1586, Latvija 
